\title{
Study of Surface Topography of CW004A Copper after PWJ Disintegration
}

\author{
Dominika Lehocká $^{1,2}$, František Botko ${ }^{1}$, Vladimír Simkulet ${ }^{1}$, Dušan Mitál'1, \\ Katarína Brezíková ${ }^{1}$, Branislav Zajac ${ }^{1}$ \\ \{dominika.lehocka@tuke.sk ${ }^{1,2}$, frantisek.botko@tuke.sk ${ }^{1}$,vladimir.simkulet@tuke.sk ${ }^{1}$ \} \\ Technical University of Kosice, Faculty of Manufacturing Technologies with a seat in Presov, \\ Bayerova 1, 08001 Presov, Slovakia ${ }^{1}$ \\ The Czech Academy of Sciences, Institute of Geonics, Studentska 1768 , \\ 70800 Ostrava - Poruba, Czech Republic ${ }^{2}$
}

\begin{abstract}
Presented article is focused on CW004A cooper surface topography evaluation disintegrated using pulsed water jet enhanced by ultrasound. Primary objective was identification and describing of disintegration pulsed water jet areas effect on material with usage of round orifice nozzle. Twenty-five samples were manufactured with variable traverse feed speed $v_{f}=0.1-20.0 \mathrm{~mm} \cdot \mathrm{s}^{-1}$, to observe and asses areas of disintegration. Surface topography signs were evaluated using surface roughness parameters $R z[\mu \mathrm{m}], R p[\mu \mathrm{m}], R v[\mu \mathrm{m}]$, mass material removal $\Delta m\left[\mathrm{mg} \cdot \mathrm{mm}^{-1}\right]$ and volume material removal $V m\left[\mathrm{~mm}^{3}\right]$. As a result of experimental research were determined three basic areas of pulsating water jet effects on disintegrated surface.
\end{abstract}

Keywords: topography, copper, pulsating water jet, surface roughness

\section{Introduction}

Waters destructive effect on different materials is commonly known from history. First time was water used for manufacturing at the start of $20^{\text {th }}$ century by Cook [1]. Currently is continual water jet (WJ) and abrasive water jet (AWJ [2], [3]) generally used for disintegration of wide range materials. Using water jets with high-pitched pressure reaches economic and technical limitations. Nowadays is tendency for disintegration of material usage of lower pressure enhanced by additional gear, which characterize pulsed water jet (PWJ). PWJ finds its purpose in many areas of industry, where can occur dangerous conditions. Dangerous conditions can cause damage, for example due to aggressive environments, increasing the operation costs, ineffectiveness, exposition of adverse substances into environment and the threat for life and health of people. These problems can be solved by replacing current technological process by pulsed liquid jet. Many efforts to obtain non continual liquid flow were recorded.

Continual jet modulation created by ultrasonic oscillation with usage additional gear ultrasonic transducer was applied in presented experimental work. Axiom of the enhanced pulse formation (Figure 1.) is founded on vibrations forming in the ultrasonic transducer, which are transmitted into fluid by usage of ultrasound guide and the ultrasound tool. Fluid jet exits the nozzle as a continual jet and in the specific distance begins forming clusters of water. Subsequently is material disintegrated by effect of water clusters impact with the high kinetic 
energy. Magneto-strictive and piezo-electric transducers are used for creation of oscillation. [4], [5]

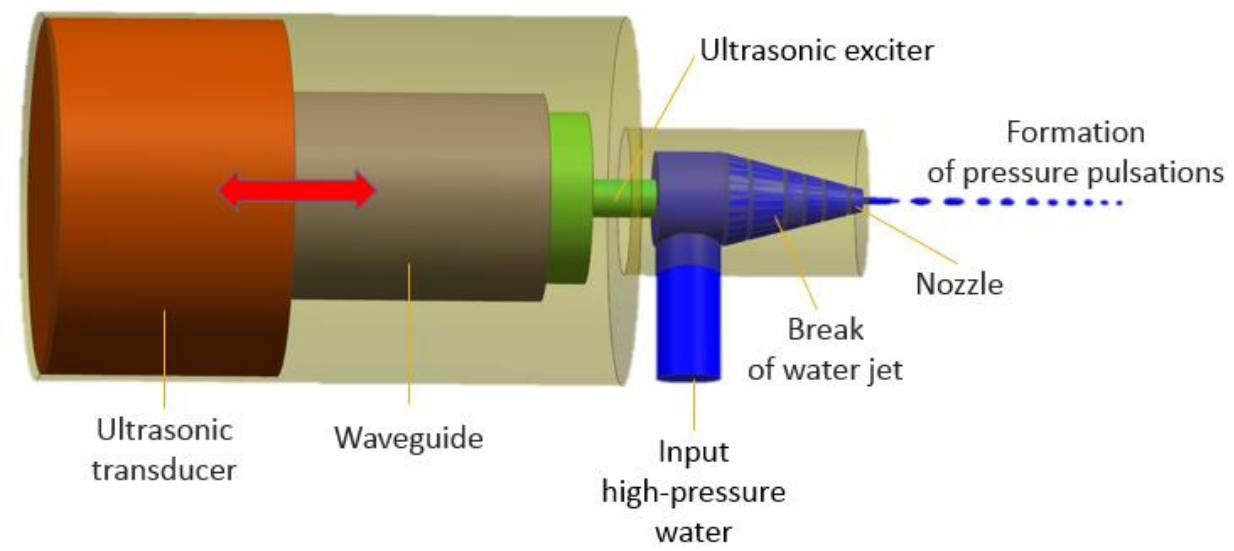

Fig. 1. Principle of ultrasound excited PWJ

Many researchers are concerned on liquid jet modulation and options of transfer pressure vibrations, for example Puchala, et al. [6], Vijay [7], [8], Foldyna, et al. [4], Foldyna \& Švehla [9] and Riha \& Foldyna [5].

Currently are some PWJ applications applied in practice, for example rock disintegration [8], renovation of the concrete structures [10], [11], surface treatment of the ornamental stones [12], for removal of burs and rust [13]. PWJ finds its application in human medicine to dental hygiene [14], in orthopedics and traumatology [15] and in the field of dermal medicine [16]. Micro pulsed water jet is applicable in the field of electronics, where is PWJ applied for microchips cooling [17].

Main objective of presented paper is describing PWJ disintegration efficiency with round nozzle and studying of new created surfaces with change of the traverse speed $v\left[\mathrm{~mm} \cdot \mathrm{s}^{-1}\right]$. Experimental research continues in research [18], [19] where PWJ static effect was described.

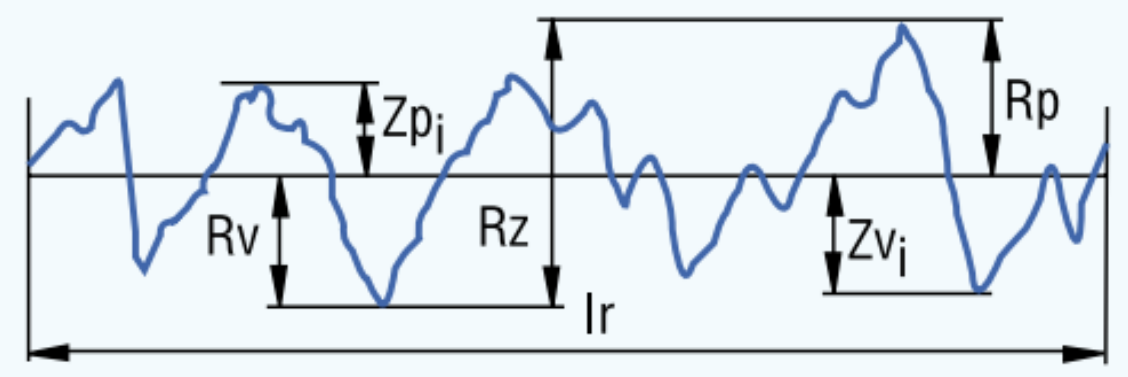

Fig. 2. Surface roughness parameters according to EN ISO 4287, where: $R z[\mu \mathrm{m}]$ - maximal height of profile, $R v[\mu \mathrm{m}]$ - maximal profile valley deep, $R p[\mu \mathrm{m}]$ - maximal profile peek height, $Z v i[\mu \mathrm{m}]$ - profile valley deep, Zpi $[\mu \mathrm{m}]$ - profile peak height, $\operatorname{lr}[\mu \mathrm{m}]$ - lenght [24]

Efficiency of disintegration was assessed using on $R z[\mu \mathrm{m}], R p[\mu \mathrm{m}], R v[\mu \mathrm{m}]$ surface roughness parameters [25], [26] (Figure 2.), mass $\Delta m\left[\mathrm{mg} \cdot \mathrm{mm}^{-1}\right]$ and volume material removal 
$V m\left[\mathrm{~mm}^{3}\right]$. Surface roughness parameters belong to main topographic characteristics of the surface.

Experimental research presented in this work follows results of authors Foldyna, et al. [20], Lehocka, et al. [22], [23], [27], [28] and Klich, et al. [21].

Experiments were conducted in collaboration between FMT with a seat in Presov and Institute of Geonics of the CAS in Ostrava. Research samples were manufactured in Institute of Geonics of the CAS in Ostrava.

\section{Set up of experiment}

Cooper CW004A (Table 1.) was selected as experimental material. Basic properties of CW004A are high electric and thermal conductivity, resistance to corrosion

Experiment procedure was held using cutting head, circular orifice nozzle StoneAge wit, hydraulic high pressure pump Hammelmann HDP 253 (maximal operational pressure 160 $\mathrm{MPa}$, maximal flow rate 67 1.min-1), ultrasound gear Ecoson WJ-UG_630-40 and industrial robot ABB IRB 6640 - 180/2.55.

Table.1. Chemical composition, mechanical and physical properties of CW004A copper

\begin{tabular}{|c|c|c|c|c|c|c|}
\hline \multicolumn{7}{|c|}{ Chemical composition [\%] } \\
\hline \multirow{2}{*}{\multicolumn{4}{|c|}{$\frac{\mathrm{Cu}+\mathrm{Ag}}{>99.90}$}} & \multicolumn{3}{|c|}{$\mathrm{O}$} \\
\hline & & & & \multicolumn{3}{|c|}{$<0.04$} \\
\hline \multicolumn{7}{|c|}{ Mechanical properties } \\
\hline \multicolumn{2}{|c|}{$\begin{array}{l}\text { Tensile strength } R_{m} \\
\text { [MPa] }\end{array}$} & \multicolumn{2}{|c|}{$\begin{array}{l}\text { Yield strength } \\
R_{p 0.2}[\mathrm{MPa}]\end{array}$} & \multicolumn{2}{|c|}{$\begin{array}{l}\text { Min. elongation } L_{0}=100 \mathrm{~mm} \\
A[\%]\end{array}$} & $\begin{array}{l}\text { Hardness } \\
\text { HB/HV }\end{array}$ \\
\hline \multicolumn{2}{|c|}{395} & \multicolumn{2}{|c|}{365} & \multicolumn{2}{|c|}{4} & $114 / 120$ \\
\hline \multicolumn{7}{|c|}{ Physical properties } \\
\hline $\begin{array}{l}\text { Density } \\
\rho\left[\mathrm{kg} \cdot \mathrm{m}^{-3}\right]\end{array}$ & & $\begin{array}{l}\text { ctrical } \\
\text { stivity } \\
2 \mu . \mathrm{m}]\end{array}$ & con & $\begin{array}{l}\text { rmal } \\
\text { ity at } 20^{\circ} \mathrm{C} \\
\left.\mathrm{n}^{-1} \cdot \mathrm{K}^{-1}\right]\end{array}$ & $\begin{array}{c}\text { Elastic modulus } \\
\text { at } 20^{\circ} \mathrm{C} \\
E[\mathrm{GPa}]\end{array}$ & $\begin{array}{c}\text { Specific heat } \\
\text { at } 20^{\circ} \mathrm{C} \\
C_{p}\left[\mathrm{~J}^{-} \mathrm{kg}^{-1} \cdot \mathrm{K}^{-1}\right]\end{array}$ \\
\hline 8890 & 0.017 & -0.0178 & & 88 & 115 & 380 \\
\hline
\end{tabular}

25 experimental samples were prepared with rectangular shape and dimensions $(1 \mathrm{x} \mathrm{w} \mathrm{x}$ t) $(50 \times 20 \times 5 \mathrm{~mm})$. Samples were produced using process conditions listed in Table 2. Variable condition was selected traverse speed $v\left[\mathrm{~mm} . \mathrm{s}^{-1}\right]$.

Every experimental sample was weighted before and after manufacturing using MettlerToledo PL303-ICweight. Mass material removal $\Delta m\left[\mathrm{mg} . \mathrm{s}^{-1}\right]$ (Table 2.) was subsequently was calculated.

Topography measurement was realized using optical MicroProf FRT. Topography characteristics (profile, shape, and $R z[\mu \mathrm{m}], R p[\mu \mathrm{m}], R v[\mu \mathrm{m}]$ roughness) and volume material removal $V m\left[\mathrm{~mm}^{3}\right]$ were assessed in software SPIP.

Table 2. Technological conditions of disintegration for changing traverse speed $v\left[\mathrm{~mm} \cdot \mathrm{s}^{-1}\right]$

\begin{tabular}{|cccccc|}
\hline \multicolumn{5}{|c|}{ Disintegration technological conditions } \\
\hline$d[\mathrm{~mm}]$ & $p[\mathrm{MPa}]$ & $z[\mathrm{~mm}]$ & $f[\mathrm{kHz}]$ & $P[\mathrm{~W}]$ & $v\left[\mathrm{~mm} \cdot \mathrm{s}^{-1}\right]$ \\
\hline 1.321 & 39 & 35 & 20.31 & 340 & $0.1-20.0$ \\
\hline
\end{tabular}




\section{Evaluation of experiment}

PWJ is composed of liquid pulses. Material is disintegrated and coextruded by pulse effect. The particles on material surface are segregated. Radial propagation of flow remove peaks and increase rate of material removal. With increasing exposition time is erosion effect more significant.

New created surface can be categorized into three effect areas of PWJ effect (Figure 3. 5.):

1. Mass material removing area $\left(v=0.1-7.0 \mathrm{~mm} . \mathrm{s}^{-1}\right)$

2. Surface roughening area $\left(v=7.0-12.0 \mathrm{~mm} \cdot \mathrm{s}^{-1}\right)$

3. Surface peening area $\left(v=12.0-20.0\right.$ and more $\left.\mathrm{mm} \cdot \mathrm{s}^{-1}\right)$

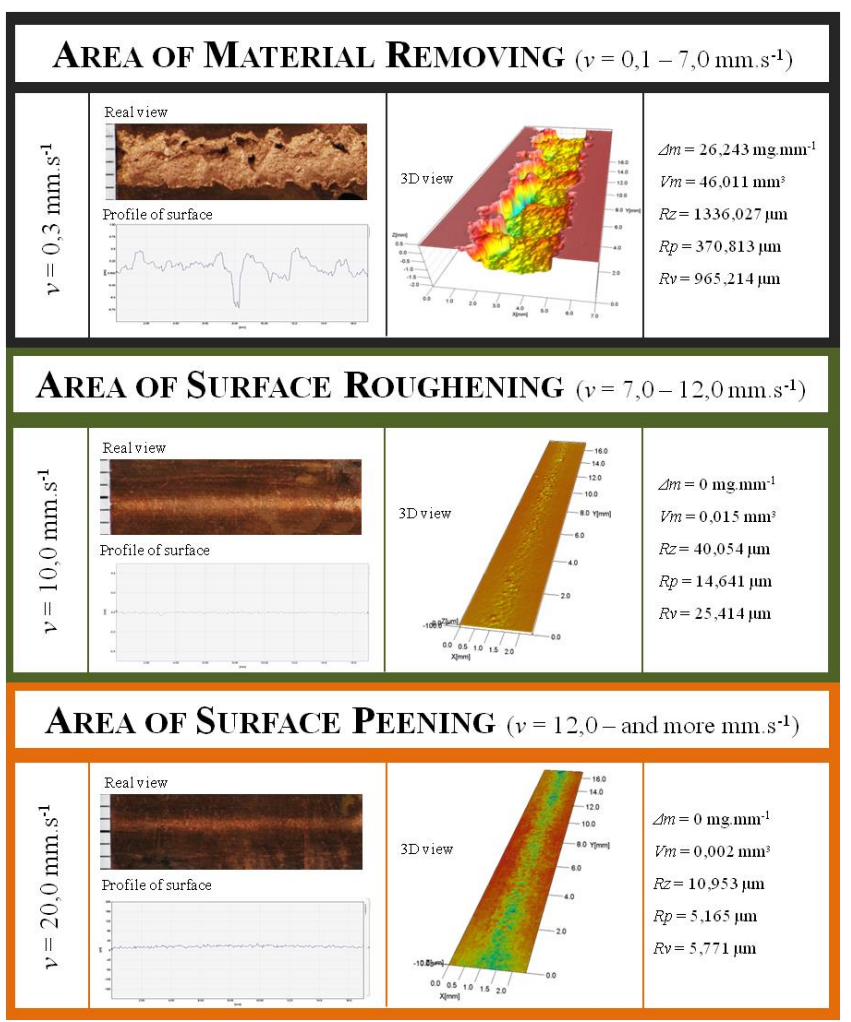

Fig. 3. Distribution of PWJ effects on disintegrated surface in accordance to traverse speed $v\left[\mathrm{~mm} \cdot \mathrm{s}^{-1}\right]$ changes 


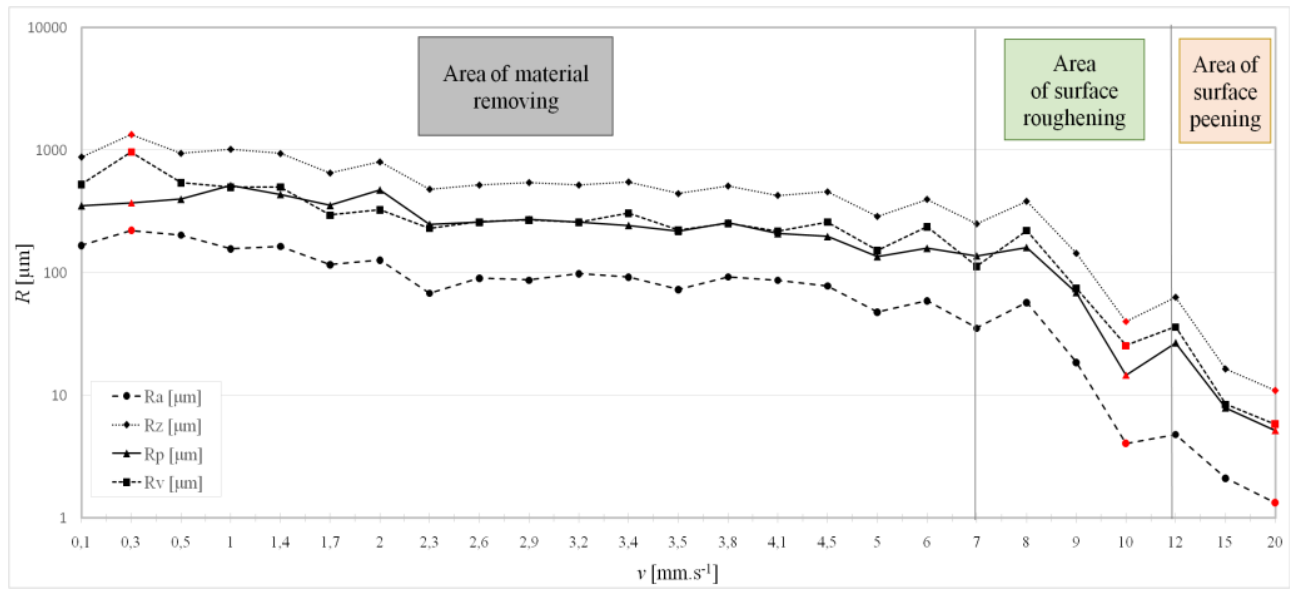

Fig. 4. Graphical dependence of PWJ erosion effects on change of roughness parameters $R z[\mu \mathrm{m}]$, $R p[\mu \mathrm{m}], R v[\mu \mathrm{m}]$

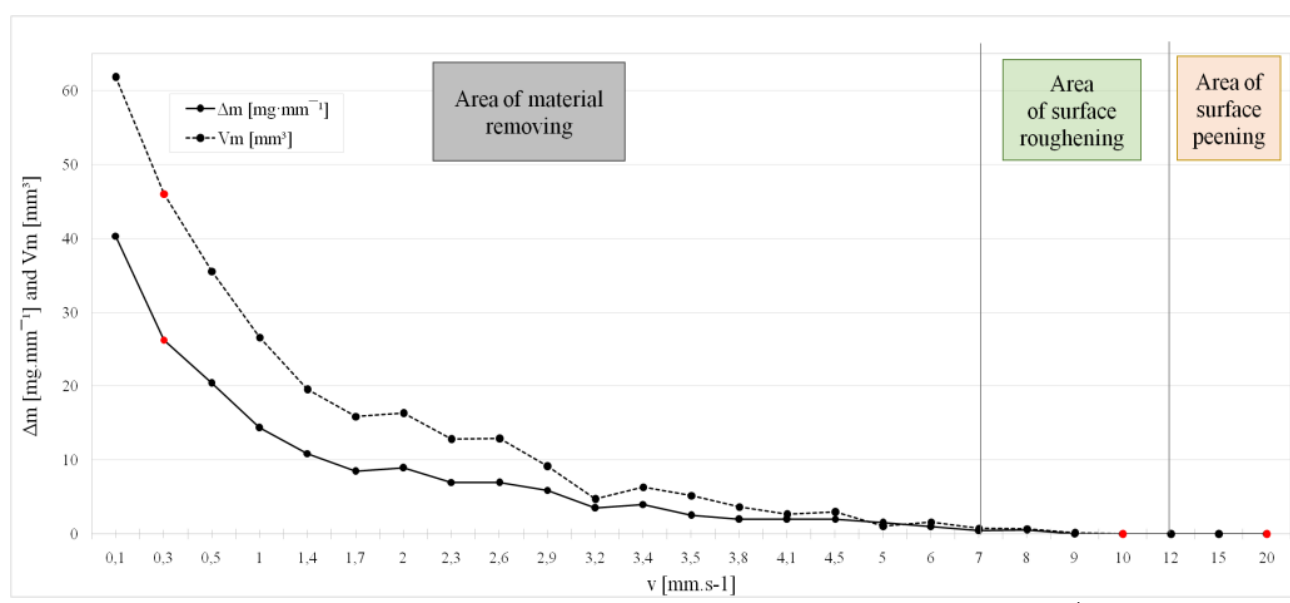

Fig. 5. Graphical dependence of PWJ erosion effects on change of mass $\Delta m\left[\mathrm{mg} . \mathrm{mm}^{-1}\right]$ and volume $V m$ $\left[\mathrm{mm}^{3}\right]$ material removal

1. Material removing area $v=0.1-7.0 ~ \mathrm{~mm}_{\mathrm{s}} \mathrm{s}^{-1}$ (for illustration - Figure 3.; groove disintegrated with using traverse speed $v=0.3 \mathrm{~mm} . \mathrm{s}^{-1}$ )

First area (area of the material removing) is characterized by intense erosive effect and significant changes of e topography. Impacting pulse with high-pitched kinetic energy disrupt surface and extrude volume of the material above surface. Subsequently radial flow amplified by repeated impact of the water clusters driven removed particles of the material and tears and cut surface. Deep and visible groove is created in eroded surface (Figure 3.). The groove is characteristic by uneven valleys and peaks with big height differences $(R z=396-1336 \mu \mathrm{m}$, $R p=135-516 \mu \mathrm{m}, R v=965-151 \mu \mathrm{m})$. Erosion pores are formed in eroded groove, which spreads and create erosive craters. Mass $\left(\Delta m=1-40 \mathrm{mg} \cdot \mathrm{mm}^{-1}\right)$ and volume $(V m=1-61$ $\mathrm{mm}^{3}$ ) material removal was significant for all samples in area of material removing. (Figure 4., 5.) 
The erosion activity observed in the material removing area can be applied in industry fields to remove of large layers of the material, revitalization of the concrete structures and surface treatment of the ornamental stones.

2. Surface roughening area $v=7.0-12.0$ mm.s ${ }^{-1}$ (shown on - Figure 3.; groove manufactured by the usage traverse speed $v=10.0 \mathrm{~mm} \cdot \mathrm{s}^{-1}$ )

Second area (surface roughening zone) is characterized by pulses effect on the surface in shorter time interval. The radial flow of water does not create erosion effect, due to sort exposition time. In second area are not created deep craters. Mass material removal $(\Delta m=0.0$ $\left.-0.5 \mathrm{mg} \cdot \mathrm{mm}^{-1}\right)$ and volume material removal $\left(\mathrm{Vm}=0.01-0.7 \mathrm{~mm}^{3}\right)$ is very low, repectively is not observed (Figure 5.). Surface topography changes are described by creation of small valleys $(R v=25.0-220 \mu \mathrm{m})$ and peaks $(R p=15.0-161 \mu \mathrm{m})$ (Figure 4.). Surface quality is higher than in first area (area of material removing) (Figure 3.).

Mentioned effects of second area can be applied in the industry for preparation before surface treatment, cleaning and surface roughening.

3. Surface peening area $v=12.0-20.0$ and more $\mathbf{m m} . \mathrm{s}^{-1}$ (shown on - Figure 3; groove disintegrated with using traverse speed $v=20.0 \mathrm{~mm} \cdot \mathrm{s}^{-1}$ )

Third area (surface peening) is characterized by zero erosion effect on materials surface $\Delta m=0 \mathrm{mg} \cdot \mathrm{mm}^{-1} ; V m=0,003 \mathrm{~mm}^{3}$ (Figure 5.). Pulsating water jet transmits too low energy for the surface disintegration. Surface craters were not observed, but very low level deformation effect occurred. Low deformation effect is characterized by the roughness parameters $(R z=10.9-16.3 \mu \mathrm{m})$ (Figure 4.). Compared to the values of roughness observed in unaffected area were $R z=5.48 \mu \mathrm{m} ; R p=2.10 \mu \mathrm{m} ; R v=3.38 \mu \mathrm{m}$.

The surfaces created with described process parameters can be applied for meliorate of utility properties of materials. Compressive residual stresses in the surface layer increase resistance to micro-cracks and thus increase durability of products.

\section{Conclusion}

Presented article defines different topographies created by pulsating water jet on CW004A copper surface and assesses different areas of PWJ effect. Based on experimental research can be concluded, that changes in PWJ efficiency can be observed with increasing of traverse speed $\left[\mathrm{mm} \cdot \mathrm{s}^{-1}\right]$.

PWJ effects on material can be divided into three areas:

1. Material removing area

2. Surface roughening area

3. Surface peening area

First area (area of material removing) can be used in many industrial fields to remove large layers or volumes of material, renovation of concrete structures and treatment of ornamental stone. Second area (surface roughening) can find its application in cleaning and roughening of surface before surface treatment. Third area (surface peening) is characterized by creation of compressive stress in material and can be applied in residual stress elimination and increase resistance to micro cracking. Surface treatment by peening can be used for higher durability under cyclic load. 
Erosion effect of PWJ depends on exposition time and force affecting material surface. Presented experimental study described possibility of regulating and influencing pulsed liquid jet disintegration efficiency for changing traverse feed speed $v\left[\mathrm{~mm} \cdot \mathrm{s}^{-1}\right]$.

Traverse feed speed $v\left[\mathrm{~mm} \cdot \mathrm{s}^{-1}\right]$ straight influence exposition time of pulsating liquid jet and workpiece and change amount of impacts on the surface. Researchers Brunton \& Thomas [18] and Foldyna, et al., [19] presented significance of impact count on disintegration efficiency. It was proven that efficiency of disintegration increase when increase count of impacts. Research presented in this article confirms conclusions in [19] and identified new areas of investigation.

Regulation of PWJ efficiency can be reached by various settings of the technological setup and process factors. Nowadays are primary regulation factors shape of nozzle orifice, lower pressures, the ultrasonic frequency modulation and optimal stand-off distance. Effect of erosion is also primary dependent on mechanical properties of material

Acknowledgments. Presented research was supported by the Slovak Research and Development Agency under Contract No. APVV-207-12. This work was supported by project VEGA 1/0682/17. Experiments were carried out with the support of the Institute of Clean Technologies for Mining and Utilization of Raw Materials for Energy Use - Sustainability Program, reg. no. LO1406 financed by Ministry of Education, Youth and Sports of the Czech Republic, and with support for the long-term conceptual development of the research institution RVO: 68145535.

\section{References}

[1] Cook, S. S.: Erosion by water hammer. Proc. R. Sot. London, Ser. A., No. 119, pp. 481-488 (1928)

[2] Hlavacek, P., et al.: Sandstone Turning by Abrasive Waterjet. Rock Mechanics and Rock Engineering. Vol. 48, pp. 2489-2493 (2015)

[3] Hutyrova, Z. et al.: Turning of wood plastic composites by water jet and abrasive water jet. International journal of advanced manufacturing technology. Vol. 84, pp. 1615-1623 (2016)

[4] Foldyna, J., Sitek, L., Švehla, B., Švehla, S.: Utilization of ultrasound to enhance high-speed water jet effects. Ultrasonics Sonochemistry. Vol. 11, pp. 131-137 (2004)

[5] Riha, Z., Foldyna. J.: Ultrasonic pulsations of pressure in a water jet cutting tool. Technical Gazette. Vol. 19, pp. 487-491 (2012)

[6] Puchala, R. J., Vijay, M. M.: Study of an ultrasonically generated cavitating or interrupted jet: Aspects of design. Proceedings of the 7th International Symposium on Jet Cutting Technology, BHRA, Cranfield, Bedford, England, Paper B2, pp. 69-82 (1984)

[7] Vijay, M. M.: Ultrasonically generated cavitating or interrupted jet. U. S. Patent No. 5, 154, 347 (1992)

[8] Vijay, M. M., Remisz, J., Foldyna, J., Grattan-Bellew, P. E.: Preweakening of Hard Rocks with Ultrasonically Modulated High Speed Pulsed Jets. Preceedings of the 12th International Conference on Jet Cutting Technology. Rouen, France, (1994)

[9] Foldyna, J., Švehla, B.: Method of generation of pressure pulsations and apparatus for implementation of this method. Czech patent, No 299412 (2008)

[10] Sitek, L., Foldyna, J., Martinec, P., Ščučka, J., Bodnárová, L., Hela, R.: Use of pul-sating water jet technology for removal of concrete in repair of concrete structures. Bal-tic Journal of Road and Bridge Engineering. Vol. 6, pp. 235-242 (2011)

[11] Dehkhoda, S., Hood, M.: An experimental study of surface and sub-surface dam-age in pulsed water-jet breakage of rocks. International Journal of Rock Mechanics \& Mining Science. Vol. 63, pp. 138-147 (2013) 
[12] Bortolussi, A., et al.: Ornamental stones surface finishing by pulsating jet: a project for an industrial application. Water Jet 2013 - Research, Development, Applications. Ostrava: Institute of Geonics AV ČR, v. v. i., pp. 17 - 24 (2013)

[13] Hnizdil, M., Raudensky, M.: Descaling by pulsating water jet. METAL 2010 - 19th International Conference on Metallurgy and Materials, Conference Proceedings. pp. 209-213 (2010)

[14] Sharma, N. C., et al.: The effect of a dental water jet with orthodontic tip on plaque and bleeding in adolescent patients with fixed orthodontic appliances. Americal journal of orthodontics and dentofacial orthopedics. Vol. 133, pp. 565-571 (2008)

[15] Hloch, S., et al.: Disintegration of bone cement by continuous and pulsating water jet. Technical Gazette. Vol. 20, pp. 593-598 (2013)

[16] Stutz, J. J., Krahl, D.: Water jet-assisted liposuction for patients with lipoedema: histologic and immunohistologic analysis of the aspirates of 30 lipoedema patients. Aes-thetic plastic surgery. Vol. 33, pp. 153-162 (2009)

[17] Hew, F.L., Timchenko, V., Reizes, J.A., Leonardi, E.: Numerical evaluation of the effectiveness of micro pulsating water jets for cooling of microchips. Proceedings of the ASME Micro/Nanoscale Heat and Mass Transfer International Conference MNHMT 2009. Vol. 2, pp. 625-633 (2009)

[18] Thomas, G. P., Brunton, J. H.: Drop impingement erosion of metals. Proceedings of the Royal Society of London. Series A, Mathematical and Physical Sciences, vol. 614, pp. 549-565 (1970)

[19] Foldyna, J. et al.: Erosion of metals by pulsating water jet. Technical Gazette. Vol. 2, pp. 381-386 (2012)

[20] Foldyna, J., et al.: Effects of pulsating water jet impact on aluminium surface. Journal of Material Processing Technology. Vol. 209, pp. 6175-6180 (2009)

[21] Klich, J., Klichova, D., Hlavacek, P.: Effects of pulsating water jet on aluminium alloy with variously modifed surface. Technical Gazette. Vol. 24, pp. 341-345 (2017)

[22] Lehocka, D., et al.: Copper alloys disintegration using pulsating water jet. Meas-urement. Vol. 82, pp. 375-383 (2016)

[23] Lehocka, D., et al.: Surface integrity evaluation of brass CW614N after impact of acoustically excited pulsating water jet, International conference on manufacturing en-gineering and materials. International Conference on manufacturing engineering and materials, ICMEM 2016, Procedia Engineering. Vol. 149, pp. 236-244 (2016)

[24] DIN EN ISO 4287, Technical standard

[25] Hreha, P., et al.: Roughness parameters calculation by means of on-line vibration monitoring emerging from AWJ interaction with material. Metrology and measurement systems. Vol. 22, pp. 315$326(2015)$

[26] Krolczyk, G., Raos, P., Legutko, S.: Experimental analysis of surface roughness and surface texture of machined and fused deposition modelled parts. Technical Gazette. Vol. 21, pp. 217-221 (2014)

[27] Lehocka, D., Klichova, D., Foldyna, J., et al.: Comparison of the influence of acousticaly enhanced pulsating water jet on selected surface integrity characteristics of CW004A copper and CW614N brass. Vol. Measurement 110, pp. 230-238 (2017)

[28] Lehocka, D., Simkulet, V., Legutko, S.: Assessment of Deformation Characteristics on CW004A Copper Influenced by Acoustically Enhanced Water Jet. Advances in Manufacturing, pp 717-724 (2018) 